\title{
The Precautionary Principle as a Framework for a Sustainable Information Society
}

\author{
Claudia Som \\ Lorenz M. Hilty \\ Andreas R. Köhler
}

\begin{abstract}
The precautionary principle (PP) aims to anticipate and minimize potentially serious or irreversible risks under conditions of scientific uncertainty. Thus it preserves the potential for future developments. It has been incorporated into many international treaties and pieces of national legislation for environmental protection and sustainable development. In this article, we outline an interpretation of the $\mathrm{PP}$ as a framework of orientation for a sustainable information society. Since the risks induced by future information and communication technologies (ICT) are social risks for the most part, we propose to extend the PP from mainly environmental to social subjects of protection. From an ethical point of view, the PP and sustainability share the principle of intergenerational justice, which can be used as an argument to preserve free space for the decisions of future generations. Applied to technical innovation and to ICT issues in particular, the extended PP can serve as a framework of orientation to avoid socio-economically irreversible developments. We conclude that the PP is a useful approach for: (i) policy makers to reconcile information society and sustainability policies and (ii) ICT companies to formulate sustainability strategies.
\end{abstract}

Claudia Som works as project manager at the Technology and Society Laboratory at Empa, the Swiss Materials Science and Technology Institute. Her research interests include the implementation of the precautionary principle for emerging technologies and qualitative risk assessment.

Prof. Dr. Lorenz M. Hilty is head of the Technology and Society Laboratory at Empa, the Swiss Materials Science and Technology Institute, and lecturer at the University of Zurich. His research interests include social and environmental aspects of information and communication technologies.

Andreas R. Köhler is a Ph.d. candidate at the Technical University of Delft, section Design for Sustainability, in the Netherlands. His research interests include innovation and technology analysis and technological risk assessment.
KEY WORDS: decisions under uncertainty, ethics, information society, pervasive computing, precautionary principle, socio-economic irreversibility, sustainability, technology development

ABBREVIATIONS: ACM: Association for computing machinery; CSR: Corporate social responsibility; EEA: European Environmental Agency; EFQM: European Foundation for Quality Management; EMAS: EcoManagement and Audit Scheme; ICT: Information and communication technology; IFIP: International Federation for Information Processing; ISO: International Standard Organization; PCs: Personal computers; PP: Precautionary principle; SR: Social responsibility; TC: Technical Committee; UN: United Nations; UNEP: United Nations Environment Programme; UNESCO: United Nations Educational, Scientific and Cultural Organization; WCED: World Commission on Environment and Development; WSIS: World Summit on the Information Society

\section{Introduction}

Novel technologies inspire in us the expectation of a better life, but simultaneously they raise new risks. The increasing power of innovation and accelerating technical progress make it difficult to anticipate environmental and social implications of novel technologies in time (Meel and Saat, 2002; WBGU, 1998). There is 'a growing tension between two aspects of science: its growing innovative powers are increasingly outrunning its capacity to anticipate the consequences' (EEA, 2001, p. 185).

After a long period of trust in technology, awareness was raised in the 1970s of the risks of technology. It became clear that technical progress not only brings natural risks into the ambit of human decisions, 
but also at the same time creates new risks. New technologies can have unacceptable side effects for society. The term 'risk society', coined by Ulrich Beck and given tangible form by the Chernobyl reactor accident, symbolises a turning point (Beck, 1986).

In contrast to natural risks, technological risks are created by human invention and innovation. They directly result from the increasing power devolving on mankind by scientific and technological progress. It is therefore necessary that society is able to make a conscious decision for or against entering into such risks, even where there is scientific uncertainty over the existence and extent of a specific risk.

The precautionary principle (PP) is a 'principle that requires public decision makers to take scientific uncertainty seriously in the pursuit of the regulatory goals of environmental and public health protection' (Fisher and Harding, 2006, p. 115). Over the last decades, the PP has gained importance in national regulations (Williamson and Hulpke, 2000) and international treaties for environmental protection and sustainable development. A typical formulation is included in Principle 15 of the Declaration of the 1992 UN Conference on Environment and Development (the 'Rio Declaration'):

In order to protect the environment, the precautionary approach shall be widely used by States according to their capabilities. Where there are threats of serious and irreversible damage, lack of full scientific certainty shall not be used as a reason for postponing costeffective measures to prevent environmental degradation (UNEP, 1992)

Wherever the PP has been used as a regulatory framework so far, it is targeted at specific subjects of protection such as the ozone layer, the North Sea, the climate, biodiversity, specific environmental compartments or specific issues of public health (for a survey, see Fisher et al., 2006; Som et al., 2004; Wiener, 2002; Williamson and Hulpke, 2000). Only in exceptional cases does the $\mathrm{PP}$ refer also to sources of impact such as persistent organic pollutants or specific technologies.

In this article, we discuss the PP from the perspective of technological development viewing new technologies and applications as sources of impact. In particular, we address the new (digital) information and communication technology (ICT). As recent technology assessment studies have shown (Hilty et al., 2005a, 2006a; Oertel et al., 2005), future ICT applications will be closely interwoven with social and environmental change. Some intended applications of ICT have the potential to induce socio-economically irreversible developments. From this point of view, we argue that the PP should be used to guide the development and application of ICT to avoid irreversible developments. Free space for the decisions of future generations should be preserved and technological lock-in avoided. In this sense, the PP can serve as a framework for the development of a sustainable information society, i.e. a society making use of ICT in a way that is consistent with the goal of sustainable development.

The article is organized as follows. We will first show that the PP, traditionally targeted to environmental and public health issues, needs to be extended to social issues. This seems necessary since there are technological developments with strong social implications, in particular in the field of (pervasive) ICT, usually discussed under the heading of 'information society'.

Second, we will clarify the relationship between the PP and sustainability by retracing them to their underlying ethical principles.

With the result of this analysis, we will return to the information society issue and make a first attempt to show how the PP could be used as a framework of orientation to guide development in the direction of a sustainable information society.

Finally, we will suggest applying the PP at the business level with regard to corporate social responsibility (CSR) and corporate sustainability strategies.

\section{The precautionary principle and social risks}

The PP has thus far been basically implemented in national regulations and international treaties for environmental protection. However, technological progress not only brings natural risks into the ambit of human decision, but also creates new types of risks. These risks can very often be seen as a potential loss of social achievements.

Basic ethical arguments for extending the domain of the precautionary principle to social risks

According to Van den Daele, the areas of damage associated with the notion of risk (originally health 
and the environment) should be extended to include social problems or changes in moral principles (Van den Daele, 1991; quoted in Wiedemann and Brüggemann, 2001). Based on this extension of the $\mathrm{PP}$, even the possibility of a change in applicable values would have to be treated as a risk and minimized. The question therefore arises whether, on the basis of current values, a possible change in values ought to be regarded as an opportunity or a risk. In any case, such processes should be given over to a social discourse (in terms of Habermas, 2001), since it would be an act of technological paternalism to establish faits accomplis by introducing a technology that implicitly stipulates moral standards without any reflection on the subject. Even if a change in applicable social values is viewed as an opportunity or a risk, the possibility that this change is initiated without a discourse must be considered a social risk.

Building on this argument, Van den Daele (2001) proposes using the $\mathrm{PP}$ to bring technological development more firmly into the sphere of influence of politics and society. The PP is intended to ensure that society is able to make a conscious and autonomous decision for or against entering into such risks, even where there is uncertainty regarding the existence and extent of a risk.

Another argument for extending the PP to social aspects is provided by Ashford, who highlights the issue of fairness in the context of risk management: 'The precautionary approach is the most appropriate basis for policy, even when large uncertainties do not exist, especially where the fairness of the distributions of costs and benefits of hazardous and products are a concern' (Ashford, 2005, p. 85). Even if there is a high level of evidence (and therefore not a 'typical' case for the PP), the social risk of an unfair distribution of costs and benefits should be treated with precaution to avoid violations of justice or equity.

Both the idea that technologies may interact with society's basic value system (that influence the 'coordinate system' in which the social discourse evaluates opportunities and risks) and the idea that fairness regarding the distribution of opportunities and risks (potential benefits and costs) of new technologies needs to be protected become demonstrative in the context of ICT impacts on society.
Specific arguments to apply the precautionary principle to information society issues

Information and communication technologies are usually associated with the buzzword 'information society', which is not clearly defined. We use the term 'information society' to denote the prospective outcome of a structural change in society stimulated by the close interaction between social practices and ICT.

There are a number of information society issues which have been discussed for decades. The history of this discourse began in 1976, when the International Federation for Information Processing (IFIP), the global umbrella association for computer professional organizations, formed a Technical Committee to deal with 'The Relationship between Computers and Society' (IFIP TC-9), which gave the many national organizations the impetus to discuss the social responsibility (SR) of ICT professions and to draw up ethical guidelines for their members. A milestone was the adoption of the 'Code of Ethics and Professional Conduct' by the Association for Computing Machinery (ACM) in 1992.

The IFIP Ethics Task Group analysed 30 codes of ethics or codes of conduct and formulated a framework for the development of such ethical guidelines by professional associations. An attempt was deliberately not made to pursue the idea of aiming for a uniform, globally applicable code (Berleur and Brunnstein, 1996). After the Internet raised new ethical issues, IFIP drew up the report on 'Ethics and the Governance of the Internet' (Berleur et al., 1999).

From the broader context of this discourse, 11 subjects referring to potential ICT impacts on social achievements emerged that repeatedly crop up because of the disagreements to which they give rise (Table I).

These 11 issues have entered the consciousness of the (specialist) public as information technology has developed from the mainframe computer era to the current ICT paradigm dominated by personal computers (PCs) and the Internet. They will not lose importance in the future, quite the contrary. The application of ICT is expected to become 'pervasive' within about a decade, that is, all aspects of daily life may be influenced by networked ICT components. This vision of future ICT application, called 'pervasive 


\section{TABLE I}

Eleven subjects referring to potential ICT impacts on social achievements (Hilty et al., 2005a, p. 40f)

Privacy

Security

Unmastered

complexity

Free speech

Intellectual property

Digital divide

Education

Gender issues

Cultural diversity

Cultural heritage

Autonomy, dependability and trust
Where does individual freedom to collect data end, in conflict with the right to information selfdetermination (which stems from the principle of autonomy)?

What level of security for an information system needs to be guaranteed for it to be responsible to use the system? Who is responsible for security flaws? Is it a criminal act or a service to society to identify and publicize security flaws?

In the case of complex, and particularly distributed, information systems, it is generally not possible to give a formal guarantee of certain properties of such systems. Does the increasing dependence on such systems result in a loss of decision-making responsibility?

What are the limits of the right to free speech with respect to the use of electronic media, when it comes into conflict with other fundamental rights? May or should there be censorship of Internet content?

Where is the boundary between information as public property, which must be available to everyone for reasons of social justice, and intellectual property, over which the owner has autonomous control?

The jeopardisation of social justice through the division of society into those who have access to the information society and those who are excluded, e.g. low-income households, the elderly, those with disabilities (also known as the 'global digital divide': the ICT gap between developed and developing countries)

Changes to the education process through the use of ICT and the implications for social justice How does the use of ICT in the workplace and in private life change social justice between genders?

What effect does ICT have on social justice between different cultures (e.g. dominance of the English language)? Will cultural diversity be preserved for future generations?

Will future generations still be able to share in our knowledge if today's digital storage media are no longer readable in the future?

Does the increasing dependence on ICT infrastructures threaten the autonomy of the individual? Will we be forced, because of the complexity of structures, to trust without having sufficient verification facilities? computing' or 'ubiquitous computing', involves the miniaturization and embedding of microelectronics in non-ICT objects and wireless networking, making computers ubiquitous in the world around us.

Technology assessment studies (Hilty et al., 2004, 2005a; Köhler and Som, 2005; Oertel et al., 2005) have shown that pervasive computing would significantly affect some of these issues, in particular:

- privacy

- security

- unmastered complexity

- digital divide

- autonomy, dependability and trust

Future applications of ICT are expected to interact intensively with social practices, which may result in profound changes to social rules and structures in the near future. Some current developments can be viewed as precursors of this development. One example is the fact that privacy regulations are increasingly difficult to implement because technology is advancing faster than the legal system can react to it. Another example is the potential of ICT to bring about an ever-finer division of labour in a globalized economy, which has substantial social implications.

We conclude from these considerations that current and future ICT applications induce social risks that may be as severe as the environmental and public health risks usually addressed by the PP. There is no reason to exclude information society issues from the domain of the PP, even if they have traditionally focused on environment and public health issues.

By making this point, we are not ignoring the fact that there are also relevant environmental effects of ICT (some of which are ecologically desirable and 
others not, see e.g. Hilty et al., 2006a; Köhler and Erdmann, 2004).

We therefore suggest using the $\mathrm{PP}$ as a framework of orientation to guide the development of a sustainable information society. Before making this claim more explicit, we first clarify the relationship between the PP and sustainable development.

\section{The link between the precautionary principle and sustainable development}

The PP and the idea of sustainable development share some common ethical grounds. We will first describe each of them and then clarify their relationship with regard to underlying ethical principles.

\section{The precautionary principle $(P P)$}

The PP is used for dealing with environmental and public health risks (and, according to newer interpretations, social risks, as discussed above) in situations where there is no acute danger, but some evidence for the existence of a relevant risk. Its purpose is to minimize risks that may become evident only in the long term and to maintain a margin for future developments.

However, the PP is interpreted very differently in its various formulations. Because of the two extreme points on a scale, it is possible to distinguish between a weak and a strong version of the PP (Dorman, 2005; Sandin, 1999; Van den Daele, 2001):
- In the weak version of the PP, precautionary measures are taken only where major, irreversible risks could occur and their scientific level of proof is high. In addition, only precautionary measures that have low costs may be taken.

- In the strong version of the PP (the other extreme), precautionary measures should be taken whenever there is any speculative evidence of a risk. Neither does the risk have to be high nor irreversible. Precautionary measures are taken irrespective of their costs (e.g. losses resulting from not using a technology).

Table II gives a survey of the differences. The discussion of the PP is connected to the issue of potential errors that can be made in managing unquantifiable risks. Under conditions of uncertainty, a risk may be overestimated ('Type I error' or 'false positive') or underestimated ('Type II error' or 'false negative'). The European Environmental Agency (EEA, 2001) investigated the history of both types of errors and found that there was a bias of underestimating risks under conditions of uncertainty. Kriebel et al. (2001) presented an overview of scientific methodologies that skew scientific results in the direction of underestimating risks.

According to Hansson (1999), the minimal version of the PP consists in moving decision making in the direction of risk neutrality. Other authors advocate stronger versions of the PP and prefer under particular conditions to err on the side of caution (e.g. Kriebel et al., 2001). Hans Jonas (1979) postulated the 'priority of the bad forecast', which corresponds to the strong PP. In the situation of

TABLE II

Weak versus strong precautionary principle

\begin{tabular}{|c|c|c|}
\hline & Weak PP & Strong PP \\
\hline & $\begin{array}{l}\text { Precautionary measures are taken only } \\
\text { where }\end{array}$ & $\begin{array}{l}\text { Precautionary measures are also taken } \\
\text { where }\end{array}$ \\
\hline Extent of threat & Major, irreversible risks might exist & Minor, reversible risks might exist \\
\hline Extent of uncertainty & The scientific level of proof is high & Only speculative evidence exists \\
\hline Extent of action & $\begin{array}{l}\text { The costs for precautionary measures } \\
\text { must be low }\end{array}$ & $\begin{array}{l}\text { The costs for precautionary measures } \\
\text { may be high }\end{array}$ \\
\hline $\begin{array}{l}\text { How mandatory is the } \\
\text { application of the PP? }\end{array}$ & Action may be taken & Action must be taken \\
\hline
\end{tabular}


uncertainty, Jonas gives precedence to the worst case scenario and argues that the likelihood of successes in technological development, as in evolution, is rather small. On the other hand, evolution can make numerous mistakes, since, unlike modern technological development, it moves forward in small steps. In addition, Jonas refers to the inherent dynamics of technical developments and poses the question as to whether an existing situation is sufficiently undesirable that one should accept any risk to improve it (Jonas, 1979, p. 75).

The variations of the PP laid down in laws and international agreements lie somewhere between the two extremes described above. The central question still remains: what level of knowledge (or proof) of a risk is sufficient to implement what precautionary measures?

Additionally, the nature of uncertainty is changing. Formerly, decision makers concentrated on the magnitude of risk and their probability. Nowadays, problems of indeterminacy and ignorance increasingly characterize the risks society faces (Wynne, 1992). Policy makers must choose whether to err on the side of caution or risk. The PP could be invoked to ensure a fair decision-making process as much as to prevent harm. Thus, instead of just waiting for scientific results, policy makers should aim for a fair and transparent democratic decision process and its underlying instruments (Anon, 2005; Ashford, 2005).

\section{Sustainable development}

Sustainable development as a political goal has its origins in the report by the World Commission on Environment and Development (WCED, 1987), also known as the Brundtland report. The essence of this idea is the combination of intragenerational and intergenerational justice. The needs of people living today should be satisfied throughout the world (intragenerational justice) without this being to the detriment of future generations (intergenerational justice). Sustainability can therefore be understood as an extension of the traditional principle of justice in space and time, i.e. to the global dimension and to the future.

The principles underlying the idea of sustainable development are often termed as 'sustainability'. Strictly interpreted, sustainability would be revolutionary, as
Meyer-Abich (2001) observes. For this very reason, he supposes, all politically relevant interpretations of sustainability contain 'an inherent guarantee that there will be no consequences' (Meyer-Abich, 2001, p. 293).

During the 1990s two extreme interpretations of sustainability emerged.

- Strong sustainability: The total natural capital of the earth must be preserved, i.e. industry and consumers, as users of nature, may live only off the 'interest' of the natural capital. Using up non-renewable resources would therefore be ruled out and renewable resources could be used only within the scope of their regeneration rate.

- Weak sustainability: The total anthropogenic and natural capital of the earth must be preserved. This means that natural capital can be reduced at will if, in return, human-created capital of the same economic value is substituted for it.

In the debates on the interpretation of sustainable development as a political goal it has become apparent that a possible consensus lies between the two extremes and has to be found again and again.

Links between the precautionary principle and sustainability from an ethical point of view

Rausch (1985) and Rehbinder (1991) recognize the sustainability and PP as having the same intention: not just to delay the overexploitation of nature, but to prevent irreversible damage.

The final declaration from a conference cosponsored by Norway and the United Nations Economic Commission for Europe in 1990 stressed the role of the $\mathrm{PP}$ as a necessary prerequisite for sustainable development:

In order to achieve sustainable development, policies must be based on the PP [...] Where there are threats of serious or irreversible damage, lack of full scientific certainty should not be used as a reason for postponing measures to prevent environmental degradation (Bergen Declaration, 1990).

Norton (1992) regards the PP as a way of protecting sustainability from its feared ineffectiveness. This 
shows that the $\mathrm{PP}$ is regarded as one of the important frameworks needed to implement the goal of sustainable development.

What are the ethical arguments behind this view? How can the PP and the pursuit of sustainability be justified on the grounds of basic ethical principles? Table III shows our attempt to map the main reasons given for (weak or strong) precautionary measures and for the pursuit of (weak or strong) sustainability to the following basic ethical principles: beneficence (do good), non-maleficence (do no harm), justice and respect for autonomy (or self-determination). It is important to note that justice here includes both intra- and intergenerational justice, the latter addressing the issue that '...present generations may be obligated by considerations of justice not to pursue policies that create benefits for themselves but impose costs on those who will live in the future' (Meyer, 2003, Introduction).

The numbering in the first column of Table III corresponds to the numbering of the following explanations.

1. A weak PP justifies a precautionary measure (such as the ban of a new technology or application) by referring to the irreversibility of the risk. This means that accepting the risk that is supposed to be induced by the new technology or application, if it actually exists, will create an irreversible situation for society. The irreversibility argument implicitly refers to the principle of intergenerational justice, because a potentially infinite number of people living in the future will be affected.

2. Besides irreversibility, a weak PP requires an additional argument to justify a precautionary measure. The cost of the measure should be low. In most practical cases, most of the cost will be the opportunity cost of not applying the technology, i.e. the cost of not doing something good that could be done otherwise. We conclude that this argument implicitly refers to the beneficence principle (do good). Furthermore, avoiding the use of a technology by regulation can also create the ideational cost of denying potential users of their free choice, a frequent argument referring to the autonomy principle.
3. A strong PP, besides accepting the justifications of the weak PP, also accepts weaker arguments to justify a precautionary measure. One of them is the argument that there is a relevant delay between cause and (the supposed harmful) effect. If the supposed risk exists, the delay explains why there is no empirical evidence for it thus far. This argument clearly assumes that it is better to err on the side of caution to avoid harm and thus refers to the non-maleficence principle (do no harm).

4. Another argument accepted in the context of the strong PP is that there would be an unfair distribution of opportunities and risks induced by the technology in case the risk actually exists: some people would benefit from the opportunities and others would bear the risk. This argument obviously refers to the principle of (distributional or social) justice.

5. Another common argument is the involuntariness of entering the risk. For example, it would not be acceptable to force people to have an electronic signature (which could potentially be misused), but there are no ethical objections against the voluntary use of this new technology. This argument refers to the autonomy principle.

6. Weak sustainability requires one to compensate for destroyed capital (of any kind) by creating capital. This addresses the principle of intergenerational justice (pass on at least the same amount of capital you have inherited) and to the beneficence principle, since creating man-made capital is viewed as 'doing good' to others and may even go beyond the necessary compensation for destruction.

7. Strong sustainability requires one to preserve the capital that cannot be recovered (e.g. non-renewable resources or biodiversity). This refers to the principle of intergenerational justice as above, but without the farreaching assumption of 'full convertibility' of capital. Since natural capital cannot generally be replaced by man-made capital, preserving it also means 'doing no harm' and therefore refers to non-maleficence. 
TABLE III

The ethical principles underlying different interpretations of the precautionary principle and sustainability

\begin{tabular}{lllll}
\hline Justification & Do good & Do no harm & Justice & Autonomy \\
\hline Weak PP & & & \\
1. Irreversibility of risk & $\mathrm{x}$ & $\mathrm{x}$ & $\mathrm{x}$ \\
$\begin{array}{l}\text { 2. Low cost of measure } \\
\text { Strong PP }\end{array}$ & & & \\
3. Delay between cause and effect & $\mathrm{x}$ & $\mathrm{x}$ & $\mathrm{x}$ \\
$\begin{array}{l}\text { 4. Unfair distribution of opportunity and risk } \\
\text { 5. Involuntariness of risk }\end{array}$ & & \\
Weak sustainability & $\mathrm{x}$ & $\mathrm{x}$ & \\
$\begin{array}{l}\text { 6. Compensate for the destruction of capital } \\
\text { Strong sustainability }\end{array}$ & $\mathrm{x}$ & $\mathrm{x}$ & \\
7. Preserve irrecoverable capital & & $\mathrm{x}$ & \\
\hline
\end{tabular}

Both weak and strong sustainabilities also address intragenerational justice, but do not differ in this respect.

We can conclude from this analysis that the common ground of the PP and sustainability is the principle of justice behind intergenerational justice, in particular, i.e. the maxim that we should not pursue policies that create benefits for us but impose costs on those who will live in the future. The weaker and the stronger interpretations of both the PP and sustainability differ in their bias towards the 'do good' principle (weaker versions) or the 'do no harm' principle (stronger versions). The principle to respect the autonomy of the individual is used both by the weak and the strong PP, in the former case against precaution and in the latter in favour of it.

The main result of this analysis is that intergenerational justice is not only the core of sustainability, but also of the PP. This view is supported by the so-called free space theory of the PP (Beyer, 1992; Köchlin, 1989). According to this theory, the PP is intended to preserve free space for the decisions and activities of future generations. This applies, for example, to future activities that pollute the environment in that the admissible environmental pollution (according to some defined risk limit) is not exhausted. Furthermore, it may also be rational to keep free space for the consequences of a modified perception and evaluation of potential impacts, since risk acceptance, the state of scientific knowledge, social values and regulations change over time ('risk of change'). Side effects of technologies that are regarded as unobjectionable today may be regarded as unacceptable damage tomorrow.

Thus, irreversibility can be used as a criterion essential to operationalizing the PP (see Hilty et al., 2004). As we will show in the following section, the criterion can help to identify information society issues that require precautionary measures.

\section{The precautionary principle as a framework for a sustainable information society}

Social aspects of ICT are to a great extent issues of potentially irreversible developments. The concept of irreversibility we are referring to is not the one of natural science (which can be traced back to the second law of thermodynamics), but a weaker, albeit relevant concept of irreversibility

The diffusion of a technology may be reversible in theory, but irreversible in practice. Once a technology has been propagated, the costs to the national economy of adjusting the course of the trend can be very high - if the legal requirements for such an adjustment are satisfied at all. In such cases, we speak of socio-economic irreversibility.

Situations of socio-economic irreversibility are also known as 'lock-in' situations (Rammel, 2003; Rip et al., 1995). Several reasons for lock-ins are discussed in the literature: 
- The rising cost of shifting to alternatives.

- The expected return on investment: Investments in research and development are strong drivers of sales; private-sector companies need to sell their new products to get the return on their investments.

- Adoption by users: Numerous users accustomed to a technology probably do not want to give it up (such as the QWERTY keyboard).

With respect to socio-economic irreversibility, the combination of the characteristics of pervasive computing shown in Table IV is relevant (Hilty et al., 2005a).

These characteristics of pervasive ICT establish the socio-economic irreversibility of this technology, which makes it a likely candidate for application of the PP. In addition, there is also an aspect of physical irreversibility, since the production of ICT requires some scarce elements (such as indium), which are almost irreversibly dissipated as components of electronic waste (Wäger et al., 2005; Widmer et al., 2005). Besides that, it should be noted that ICT can also be applied for the benefit of sustainable development (Hilty et al., 2005b; Köhler and Som, 2005). If all types of environmental impacts of ICT are taken into account, the overall effect seems to be ambivalent, i.e. depending on the framework conditions under which ICT is applied (Hilty et al., 2006a; Köhler and Erdmann, 2004).

Two basic approaches to applying the PP to ICT developments can be derived from our discussion of the PP in 'The link between the precautionary principle and sustainable development' section above. The first approach is to keep as much space for future development open as possible, since we cannot anticipate today what the needs of future generations will be. This means, on the one hand, preventing irreversible damages to the environment, human health and social achievements, and, on the other hand, keeping open technological development trajectories and avoiding path-dependencies (Rammel, 2003).

For the development of new ICT, such an approach should include:

- Preferring open standards for all types of interfaces among ICT products to proprietary standards, because they are essential for avoiding strong path dependency and trends towards market dominance, which destroy fair competition and diversity.

- Preferring less complex technical solutions to more complex ones, because unmastered technical complexity fosters investment in analysis and adaptation, which fosters the path dependency of the development.

The second approach is participation (for an overview, see Joss and Bellucci, 2002; Renn et al., 2003; UNESCO and COMEST, 2005), i.e. involving stakeholders in a dialogue on the development and application of novel technologies. It is known to aid in detecting early warnings, assessing technical alternatives, preventing conflicts and developing safer products (Fergus and Rowney, 2005; Jeurissen, 2004; WBGU, 1998).

A stakeholder dialogue on technology development could even lead to a 'new production of technology' yielding 'socially robust technology' (as opposed to only technically robust technology), in analogy to Novotny's concept of the 'new production of knowledge' or 'Mode 2 science' leading to 'socially robust knowledge' (Novotny et al., 2001, 2003). In the field of ICT, society is far away from an informed stakeholder dialogue. As the UN World Summit on the Information Society (WSIS) in 2005 has shown once again, the rebound effects of ICT (Hilty, 2006; Hilty et al., 2006b) and other potential side effects are widely ignored and naïve political ideas such as 'poverty reduction by ICT' or 'access for all' promoted.

The PP can be used as a general framework to guide policy makers at any level to give their information society policies an ethical orientation. Give preference to open standards and to less complex technology and create opportunities for an informed stakeholder dialogue. These precautionary measures will help to avoid lock-in and to preserve free space for the decisions of future generations.

\section{The precautionary principle at the business level}

If the PP is to be effective in avoiding social, environmental and public health risks of new technologies 


\section{TABLE IV}

Characteristics of pervasive computing that foster socio-economic irreversibility

Mass consumer technology Interconnection of the physical world and the virtual world

Compatibility

Complexity

\section{ICT components will increasingly be embedded in everyday objects}

There is a trend to interconnect the physical world (world of things) with the virtual world (world of data) in real time, that is, more and more data will be synchronized with physical processes via sensors, and vice versa via actuators. The opportunities this synchronization brings about for the organization of production and consumption processes tend to make pervasive computing a new critical infrastructure

The diffusion of novel ICT depends heavily on compatibility issues. The requirement that new ICT products remain compatible with existing ones narrows the range of future development trajectories considerably. The compatibility issue also compromises competition in the ICT sector by creating 'winner takes all' (WTA) market structures, an effect which further reduces the open space for future developments

Pervasive ICT systems form complex distributed systems. Such a system may exhibit emergent properties which have not been intended or foreseen by its designer and cannot be controlled, because there is no designer of the system as such. Society will be increasingly forced to rely on unmastered distributed systems because switching them off or reorganizing them will have unpredictable consequences such as pervasive ICT, it should also be incorporated into the business strategies of companies developing ICT and its applications. For their long-term success, a stakeholder dialogue about information society issues is crucial. It is usually easier and cheaper to avoid unsustainable development paths at an early stage of the innovation chain.

From a business-ethical point of view, applying the PP to technological innovation is an issue of CSR. However, the CSR debate has only rarely addressed this issue thus far. As Rip notes, 'CSR now starts to include technology and innovation' (Rip, 2005). Viewed from a PP perspective, technology and innovation are much more relevant than the company's daily operational business, which is often the focus of CSR activities. However, there is no approach so far to integrate precautionary strategies in management methodology beyond the consideration of 'hard' liability issues (which was one of the early ideas of CSR, Votaw, 1972). In order to develop such an approach, in particular for the ICT industry, would be a task for future research. A first step towards this goal could be to put a reference to the PP in ISO 26000, a designation of the future International Standard giving guidance on SR.

The PP is not just another add-on extending the list of management approaches such as quality (i.e. ISO 9000, EFQM), knowledge management (i.e. intellectual capital), environmental management (i.e. ISO 14000, EMAS), risk management (i.e. ISO 25700 , in preparation) or CSR (i.e. SA 8000, AA 1000) (Maxwell et al., 2006). These approaches are already lacking integration in traditional management systems. In just the same way as they should be part of an overall sustainability strategy (as Bieker et al., 2001, propose) they should be geared to the PP. As we have shown above, the ethics behind sustainability and the PP is very similar. If one accepts the prediction that sustainability is one of the salient issues managers will face over the coming years (Bieker et al., 2001; Gauthier, 2005; Isenmann and Lenz, 2004; Morimoto et al., 2005; Steurer et al., 2005), the PP should comprise part of the sustainability strategy of a company, because it emphasises the issue of socio-economic irreversibility in a technology development context - an issue which appears undervalued in the traditional approaches to sustainability.

\section{Conclusion}

We have presented arguments for extending the PP from mainly environmental and health domains to include social subjects for protection. One main reason for this claim is the self-apparent interaction between ICT development and information society issues; there precaution is needed to bring technology 
development under better societal control and to avoid socio-economically irreversible developments. Our analysis of the PP and sustainability has shown that these two ideas share some common ground: the goal of preserving free space for the decisions of future generations. Due to the close relationship between the PP and sustainable development, the PP can be regarded as a general framework for policy makers at all levels to support the goal of sustainable development, in particular to reconcile information society and sustainability policies, targeting a sustainable information society. Furthermore, the PP as a framework of orientation should become a part of corporate strategies for companies in the ICT sector, if not in all sectors developing new technologies with a potential for deep societal change.

\section{References}

Anon: 2005, 'The Precautionary Principle: Implications for Research and Policy Making', Human and Ecological Risk Assessment 11, 3-4.

Ashford, N. A.: 2005, 'Incorporating Science, Technology, Fairness and Accountability in Environmental, Health, and Safety Decisions', Human and Ecological Risk Assessment 11, 85-96.

Beck, U.: 1986/1992, Risikogesellschaft. Auf dem Weg in eine andere Moderne (Suhrkamp, Frankfurt).

Bergen Declaration: 1990, 'Bergen Ministerial Declaration on Sustainable Development in the ECE Region', UN Doc. A/CONF.151/PC/10 (1990), Reprinted at 1 Year Book International Environmental Law 429.

Berleur, J. and K. Brunnstein (eds.): 1996, A Handbook Prepared by the IFIP Ethics Task Group (Chapman \& Hall, London, UK).

Berleur, J., P. Ducenoy and D. Whitehouse (eds.): 1999, Ethics and the Governance of the Internet - To Promote Discussion Inside the IFIP National Societies (IFIP, Laxenburg), http://www.info.fundp.ac.be/ $\sim j b l /$ IFIP/cadresIFIP.html, SIG 9.2.2 'Ethics and Internet Governance'. Accessed 27 Aug 2006.

Beyer, H. M.: 1992, 'Das Vorsorgeprinzip in der Umweltpolitik', Schriftenreihe Wirtschafts- und Sozialwissenschaften, Vol. 10 (Verlag Wissenschaft \& Praxis, Germany).

Bieker, T., T. Dyllick, C. U. Gminder and K. Hockerts: 2001, Towards a Sustainability Balanced Scorecard. Linking Environmental and Social Sustainability to Business Strategy (IWÖ-HSG, St. Gallen).
Dorman, P.: 2005, 'Evolving Knowledge and the Precautionary Principle', Ecological Economics 53, 169-176.

EEA (European Environmental Agency): 2001, Late Lessons from Early Warnings: The Precautionary Principle 1896-2000 (EEA, Copenhagen), http://reports.eea. eu.int/environmental_issue_report_2001_22/en. Accessed 27 Aug 2006.

Fergus, A. H. T. and J. I. A. Rowney: 2005, 'Sustainable Development: Epistemological Frameworks \& an Ethic of Choice', Journal of Business Ethics 57, 197-207. doi:10.1007/s10551-004-5093-6.

Fisher, E. and R. Harding: 2006, 'The Precautionary Principle and Administrative Constitutionalism: The Development of Frameworks for Applying the Precautionary Principle', in E. Fisher, J. Jones and R. von Schomberg (eds.), Implementing the Precautionary Principle (Edward Elgar Cheltenham, UK/Northampton MA, USA), pp. 113-136.

Fisher, E., J. Jones and R. von Schomberg: 2006, 'Implementing the Precautionary Principle: Perspectives and Prospects', in E. Fisher, J. Jones and R. von Schomberg (eds.), Implementing the Precautionary Principle (Edward Elgar Cheltenham, UK, Northampton, MA, USA), pp. 1-11.

Gauthier, C.: 2005, 'Measuring Corporate Social and Environmental Performance: The Extended LifeCycle Assessment', Journal of Business Ethics 59, 199206. doi:10.1007/s10551-005-3416-x.

Habermas, J.: 2001, Zukunft der menschlichen Natur: auf dem Wege zur liberalen Eugenik (Suhrkamp, Frankfurt am Main).

Hansson, S. O.: 1999, 'Adjusting Scientific Practices to the Precautionary Principle', Human Ecological Risk Assessment 5(5), 909-921.

Hilty, L. M.: 2006, 'Risiken und Nebenwirkungen der Informatisierung des Alltags', in F. Mattern (ed.), Der Computer im 21. Jahrhundert. Die Informatisierung des Alltags. Perspektiven, Technologien, Auswirkungen (Springer Verlag, Berlin).

Hilty, L. M., P. Arnfalk, L. Erdmann, J. Goodman, M. Lehmann and P. Wäger: 2006, 'The Relevance of Information and Communication Technologies for Environmental Sustainability-A Prospective Simulation Study', Environmental Modelling \& Software 21(11), 1618-1629.

Hilty, L. M., S. Behrendt, M. Binswanger, A. Bruinink, L. Erdmann, J. Froehlich, A. Köhler, N. Kuster, C. Som and F. Wuertenberger: 2005a, The Precautionary Principle in the Information Society - Effects of Pervasive Computing on Health and Environment, 2nd Revised Edition (Swiss Center for Technology Assessment (TA-SWISS), Bern, 
Switzerland (TA46e/2005) and the Scientific Technology Options Assessment at the European Parliament (STOA 125 EN)), http://www.ta-swiss.ch/wwwsupport/reportlists/publicationsinfosoc_d.htm. Accessed 27 Aug 2006.

Hilty, L. M., A. Köhler, F. Von Schéele, R. Zah and T. Ruddy: 2006, 'Rebound Effects of Progress in Information Technology', Poiesis \& Praxis: International Journal of Technology Assessment and Ethics of Science 4, 19-38. doi:10.1007/s10202-005-0011-2.

Hilty, L. M., E. K. Seifert and T. Treibert (eds.): 2005, Information Systems for Sustainable Development (Idea Group Publishing, Hershey).

Hilty, L. M., C. Som and A. Köhler: 2004, 'Assessing the Human, Social, and Environmental Risks of Pervasive Computing', Human and Ecological Risk Assessment 10(5), 853-874.

Isenmann, R. and Ch. Lenz: 2004, 'Internet Use for Corporate Environmental Reporting: Current Challenges-Technical Benefits-Practical Guidance', Business Strategies and the Environment 3, 181-202.

Jeurissen, R.: 2004, 'Institutional Conditions of Corporate Citizenship', Journal of Business Ethics 53(1-2), 87-96.

Jonas, H.: 1979, Das Prinzip der Verantwortung. Versuch einer Ethik für die technologische Zivilisation (Suhrkamp, Frankfurt).

Joss, S. and S. Bellucci: 2002, Participatory Technology Assessment, European Perspectives (Centre for Study of Democracy University Westminster, Swiss Center for Technology Assessment, Karlsruhe).

Köchlin, D.: 1989, Das Vorsorgeprinzip im Umweltschutzgesetz, Unter besonderer Berücksichtigung der Emissions- und Immissionsgrenzwerte, Neue Literatur zum Recht (Hebling \& Lichtenhahn, Basel und Frankfurt am Main, Germany).

Köhler, A. and L. Erdmann: 2004, 'Expected Environmental Impacts of Pervasive Computing', Human and Ecological Risk Assessment 10(5), 831-852.

Köhler, A. and C. Som: 2005, 'Effects of Pervasive Computing on Sustainable Development', IEEE Technology and Society Magazine 24(1), 15-23.

Kriebel, D., J. Tickner, P. Epstein, J. Lemons, R. Levins, E. L. Loechler, M. Quinn, R. Rudel, T. Schettler and M. Soto: 2001, 'The Precautionary Principle in Environmental Science', Environmental Health Perspective 109, 871-876.

Maxwell, D., W. Sheate and R. van der Vorst: 2006, 'Functional and Systems Aspects of the Sustainable Product and Service Development Approach for Industry', Journal of Cleaner Production 14, 1466-1479.
Meel, M. and M. Saat: 2002, 'Ethical Life Cycle of an Innovation', Journal of Business Ethics 39, 21-27.

Meyer, L.: 2003, 'Intergenerational Justice', in E. N. Zalta (ed.), The Stanford Encyclopaedia of Philosophy, Winter 2003 Edition, http://plato.stanford.edu/archives/sum 2003/entries/justice-intergenerational/\#. Accessed 04 Sept 2007.

Meyer-Abich, K.-M.: 2001, 'Nachhaltigkeit - ein kulturelles, bisher aber chancenloses Wirtschaftsziel', Zeitschrift für Wirtschafts- und Unternehmensethik (Zfwu) 2(3), 291-310.

Morimoto, R., J. Ash and C. Hope: 2005, 'Corporate Social Responsibility Audit: From Theory to Practice', Journal of Business Ethics 62, 315-325. DOI: 10.1007/ s10551-005-0274-5

Norton, B. G.: 1992, 'Sustainability, Human Welfare and Ecosystem Health', Environmental Values 1, 97-112.

Novotny, H., P. Scott and M. Gibbons: 2001, Re-thinking Science: Knowledge and the Public in an Age of Uncertainty (Policy Press, Cambridge).

Novotny, H., P. Scott and M. Gibbons: 2003, 'Introduction 'Mode 2' Revised: The New Production of Knowledge', Minerva 41, 179-194.

Oertel B., M. Wölk, L. M. Hilty and A. Köhler: 2005, Security Aspects and Prospective Applications of RFID Systems (Bundesamt für Sicherheit in der Informationstechnik, Bonn), http://www.bsi.de/fachthem/ rfid/RIKCHA_englisch_Layout.pdf. Accessed 27 Aug 2006.

Rammel, C.: 2003, 'Sustainable Development and Innovations: Lessons from the Red Queen', International Journal of Sustainable Development 6, 395-416.

Rausch, H.: 1985, Kommentar zum Umweltschutzgesetz (Schulthess Polygraphischer Verlag, Zürich, Switzerland).

Rehbinder, E.: 1991, 'Das Vorsorgeprinzip im internationalen Vergleich', in U. Battis, E. Rehbinder and W. Gerd (eds.), Umweltrechtliche Studien, Band 1, Technik und Umwelt, Energie, Recht (Werner Verlag GmbH, Düsseldorf), pp. 1-275.

Renn, O., M. Dreyer, A. Klinke, C. Losert, A. Stirling, P. van Zwanenberg, U. Müller-Herold, M. Morosini and E. Fisher: 2003, 'The Application of the Precautionary Principle in the European Union', Final Document, EU-project: Regulatory Strategies and Research Needs to Compose and Specify a European Policy on the Application of the Precautionary Principle (PrecauPri).

Rip, A.: 2005, 'Technology Assessment as Part of the Co-Evolution of Nanotechnology and Society: The Thrust of the TA Program in Nanoned', Paper 
contributed to the Conference on Nanotechnology in Science, Economy, and Society, Marburg, 13-15 January 2005.

Rip, A., T. J. Misa and J. Scott (eds.): 1995, Managing Technology in Society: The Approach of Constructive Technology Assessment (Pinter, London, UK).

Sandin, P.: 1999, 'Dimensions of the Precautionary Principle', Human Ecological Risk Assessment 5(5), 889907.

Som, C., L. M. Hilty and T. Ruddy: 2004, 'The Precautionary Principle in the Information Society', Human and Ecological Risk Assessment 10, 787-799.

Steurer, R., M. E. Langer, A. Konrad and A. Martinuzzi: 2005, 'Corporations, Stakeholders and Sustainable Development I: A Theoretical Exploration of Business-Society Relations', Journal of Business Ethics 61, 263-281. doi:10.1007/s10551-005-7054-0.

UNEP (United Nations Environment Programme): 1992, The Rio Declaration on Environment and Development, Principle 15, http://www.unep.org/Docume nts/Default.asp?DocumentID=78\&ArticleID $=1163$. Accessed 27 Aug 2006.

UNESCO and COMEST (World Commission on the Ethics of Scientific Knowledge and Technology): 2005, The Precautionary Principle (UNESCO, France).

Van den Daele, W.: 1991, 'Risiko-Kommunikation: Gentechnologie', in H. Jungermann, B. Rohrmann and P. M. Wiedemann (eds.), Risikokontroversen: Konzepte, Konflikte, Kommunikation (Springer, Berlin), pp. 11-61.

Van den Daele, W.: 2001, 'Zur Reichweite des Vorsorgeprinzips-rechtliche und politische Perspektiven', in L. Joachim (ed.), Gentechnik im nichtmenschlichen Bereich-was kann und was sollte das Recht regeln (Arno Spitz GmbH, Berlin, Germany), pp. 101-125.

Votaw, D.: 1972, 'Genius Became Rare: A Comment on the Doctrine of Social Responsibility Pt 1', California Management Review 15(2), 25-31.

Wäger, P., M. Eugster, L. M. Hilty and C. Som: 2005, 'Smart Labels in Municipal Solid Waste-A Case for the Precautionary Principle?', Environmental Impact Assessment Review 25, 567-586.
WBGU (Wissenschaftlicher Beirat der Bundesregierung globale Umweltveränderungen): 1998, Welt im Wandel-Strategien zur Bewältigung globaler Umweltrisiken (Springer Verlag, Berlin, Germany).

WCED (World Commission on Environment, Development): 1987, Our Common Future (Oxford Press, Oxford, UK).

Widmer, R., H. Oswald-Krapf, S. Deepali-Kehtriwal, M. Schnellmann and H. W. Böni: 2005, 'Global Perspectives on e-Waste', Environmental Impact Assessment Review. Special Issue: Environmental and Social Impacts of Electronic Waste Recycling 25(5), 436-458.

Wiedemann, P. M. and A. Brüggemann: 2001, Vorsorge aus der Perspektive der Sozialwissenschaft: Probleme, Sachstand und Lösungsansätze, Arbeit zur Risiko-Kommunikation, Vol. 82 (Forschungszentrum Jülich $\mathrm{GmbH}$, Jülich, Germany).

Williamson, G. H. and H. Hulpke: 2000, 'Das Vorsorgeprinzip, Internationaler Vergleich, Möglichkeiten und Grenzen, Lösungsvorschläge', UWSF-Zeitschrift für Umweltchemie und Ökotoxikologie 12, 27-39.

Wiener, J. B.: 2002, 'Precaution in a Multirisk World', in D. J. Paustenbach (ed.), Human and Ecological Risk Assessment: Theory and Practice (Wiley, New York, NY), pp. 1509-1531.

Wynne, B.: 1992, 'Uncertainty and Environmental Learning', Global Environmental Change 2(2), 111-127.

Claudia Som and Lorenz M. Hilty Empa, Swiss Federal Laboratories for Materials Testing and Research, Lerchenfeldstr. 5, 9014 St. Gallen, Switzerland E-mail:claudia.som@empa.ch; lorenz.hilty@empa.ch

Andreas R. Köhler Delft University of Technology, DfS (Design for Sustainability programme), Landbergstraat 15, 2628 CE, Delft, The Netherlands E-mail:a.r.koehler@tudelft.nl 